\section{In Vitro and In Vivo Antimalarial Activities of a Carbohydrate Antibiotic, Prumycin, against Drug-resistant Strains of Plasmodia}

Sir:

In the course of our program to discover antimalarial antibiotics active against drug-resistant parasites, by screening soil microorganisms and antibiotic library of the Kitasato Institute for Life Sciences, we previously reported on various microbial metabolites exhibiting potent antimalarial properties ${ }^{1 \sim 4)}$. Now, we find that prumycin ${ }^{5 \sim 7)}$, a compound in the antibiotic library of our institute, has potent and moderately selective antimalarial activity in vitro and in vivo. We report here the antimalarial profiles of prumycin and its derivatives (Fig. 1) in comparison with those of clinically used antimalarial drugs, and also present some conclusions on structure-activity relationships.

Prumycin was purified from the cultured broth of Streptomyces sp. strain No. F-1028,6). The derivatives (2 4) were synthesized according to our previous report ${ }^{7}$. Benzyl 4-amino-2-(benzyloxycarbonyl) amino-2,4dideoxy- $\alpha$-L-arabinopyraside (5) was a generous gift of Nippon Kayaku Co. LTD., (Japan). The compounds (6 $\sim 8)$ were prepared from 5 with the protected amino acids (DCC, $\mathrm{CH}_{2} \mathrm{Cl}_{2}$, r.t.), followed by deprotections.
In vitro activities against Plasmodium falciparum strains K1 (drug-resistant) and FCR3 (drug-sensitive), and cytotoxicity against human diploid embryonic cell line MRC-5, were measured as described previously ${ }^{1}$. Rodent malaria-derived strains for in vivo 4-days suppressive testing, $P$. berghei $\mathrm{N}$ (drug-sensitive) and $P$. yoelii ssp. NS (chloroquine-resistant) were used to assess in vivo efficacy as reported previously ${ }^{1,2}$. Prumycin was dissolved in water, while other test compounds were solubilized in $10 \%$ DMSO-Tween 80 aqueous solution. The formulated samples were administered subcutaneously (s.c.) to mice two hours after infection with parasites (Day 0), and then once a day for 3 days (Days 1 3). On the day after the last treatment (Day 4), thin blood films were made from the tail blood of the mice, and the parasitaemia was determined as described previously ${ }^{2}$.

Table 1 shows the in vitro antimalarial activities of prumycin, its derivatives and some standard antimalarial drugs. Prumycin and $\alpha$-prumycin had similar activity to choroquine against the drug-resistant $\mathrm{K} 1$ strain of $P$. falciparum, but were less potent than the clinically used antimalarials artemether, artemisinin and artesunate. Furthermore, prumycin and $\alpha$-prumycin showed similar activities against the drug-sensitive FCR3 strain of $P$. falciparum. However, the $\mathrm{IC}_{50}$ values of prumycin derivatives $(\mathbf{3} \sim \mathbf{8})$ against the $\mathrm{K} 1$ strain were $>12.5 \mu \mathrm{g} / \mathrm{ml}$.

Fig. 1. Structures of prumycin and its derivatives.<smiles>CC(N)C(=O)NC1OC(N)C(O)C(O)O1</smiles>

Prumycin (1)<smiles>NC1COC(OCc2ccccc2)C(NC(=O)OCc2ccccc2)C1</smiles><smiles>CC(N)C(=O)NC1OC(O)C(N)C(O)C1O</smiles>

$\alpha-P r u m y c i n(2)$<smiles>NCC(=O)NC1COC(N)C(O)C1O</smiles><smiles>COC1OCC(NC(=O)C(C)N)C(O)C1N</smiles>

Methyl B-prumycinide (3)<smiles>NC1CC(NC(=O)C2CCCN2)C(O)COC1O</smiles>

De-Alanyl-prolinylprumycin (7)

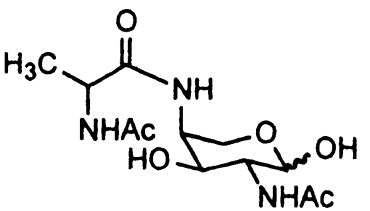

$N, N^{\prime}$-Diacetylprumycin (4)<smiles>CCC(C)C(N)C(=O)NC1COC(N)C(O)C1O</smiles> 
Table 1. Antimalarial activities of prumycin, its derivatives and the antimalarial drugs against $\mathrm{K} 1$ and FCR3 strains of Plasmodium falciparum.

\begin{tabular}{lcc}
\hline & \multicolumn{2}{c}{ IC50 $(\mu \mathrm{g} / \mathrm{ml})$} \\
\cline { 2 - 3 } Compound & K1 strain* & FCR3 strain** \\
\hline Prumycin (1) & $\mathbf{0 . 1 6}$ & $\mathbf{0 . 1 7}$ \\
$\alpha$-Prumycin (2) & $\mathbf{0 . 3 4}$ & $\mathbf{0 . 1 4}$ \\
3 & $>12.5$ & ND \\
4 & $>12.5$ & ND \\
5 & $>12.5$ & ND \\
6 & $>12.5$ & ND \\
7 & $>12.5$ & ND \\
8 & $>12.5$ & ND \\
Artemisinin & 0.01 & 0.006 \\
Artemether & 0.0023 & 0.0007 \\
Artesunate & 0.0042 & 0.001 \\
Chloroquine & 0.3 & 0.02 \\
\hline * drug-resistant strain & ** drug-sensitive strain & $* \star *$ not determined
\end{tabular}

We then investigated the cytotoxicities of prumycin and $\alpha$ prumycin against MRC-5 cells and found them to be, respectively, 3.6 and $1.2 \mu \mathrm{g} / \mathrm{ml}$. Prumycin and $\alpha$-prumycin showed moderate to low selectivity indexes, with ratios in the ranges of 22.5 3.5 and 21.3 8.6 for the MRC-5 cells/K1 strain and MRC-5 cells/FCR3 strain, respectively.

The lack of antimalarial activity of prumycin derivatives (3 $\mathbf{8})$ in comparison to prumycin provides interesting information on structure-activity relationships. Thus introduction of a methyl group on the hydroxyl (to give 3) and acetylating the two primary amino groups (resulting in 4) destroys activity. Furthermore, replacement of the L-alanine group on the amino moiety at C-4 with, respectively, L-glycine (6), L-proline (7), and L-isoleucine (8) also destroys activity. These results suggest that a free anomer at $\mathrm{C}-1$, amino groups at $\mathrm{C}-2$, and the methyl group at L-alanine all play an important role in the antimalarial activity of prumycin.

Further studies are necessary to extend the structureactivity relationships of prumycin-related antimalarial compounds.

Table 2 shows a preliminary comparison of the in vivo subcutaneous antimalarial activities of prumycin and the standard antimalarial drugs. Prumycin had moderate activity against both rodent malaria-derived $P$. berghei $\mathrm{N}$ and $P$. yoelii ssp. NS, but was less effective than the clinically used antimalarials artemether and artesunate. The $\mathrm{ED}_{90}$ value of prumycin $(27.8 \mathrm{mg} / \mathrm{kg})$ against the chloroquine-resistant strain ( $P$. yoelii ssp. NS) was much lower than that of chloroquine $(>100 \mathrm{mg} / \mathrm{kg})$, and was
Table 2. In vivo subcutaneous antimalarial activities of prumycin, artemether, artesunate and chloroquine against $P$. berghei $\mathrm{N}$ and $P$. yoelii ssp. NS.

\begin{tabular}{llcc}
\hline Parasite & Compound & ED50 $(\mathrm{mg} / \mathrm{kg})$ & ED90 $(\mathrm{mg} / \mathrm{kg})$ \\
\hline P. berghei $\mathrm{N}^{*}$ & Prumycin & 6.2 & 17.0 \\
& Artemether & 0.95 & 3.8 \\
& Artesunate & 1.7 & 10.0 \\
& Chloroquine & 1.5 & 2.5 \\
& & & \\
P. yoelii ssp. NS N $^{*}$ Prumycin & 10.2 & 27.8 \\
& Artemether & 1.1 & 5.1 \\
& Artesunate & 0.4 & 26.0 \\
& Chloroquine & 4.5 & $>100.0$ \\
& & & \\
& & &
\end{tabular}

* drug-sensitive strain ** chloroquine-resistant strain

similar to that of artesunate.

It is known that prumycin has inhibitory activities against phytopathogenic fungi such as Sclerotinia sclerotiorum and Botorytis cineria ${ }^{5,6)}$, and against tumor cells ${ }^{8-11)}$, and that its mode of anti-fungal action in growing cells of $B$. cineria involves selective inhibition of protein synthesis ${ }^{12}$. Furthermore, we previously reported that it inhibits both protein synthesis and DNA synthesis in cultured HeLa S3 cells ${ }^{8)}$. However, the finding of the antimalarial activities of prumycin and its derivative is novel and the above data are the first report of such properties.

We previously reported that the $\mathrm{LD}_{50}$ values (i.v. and i.p., in mice) of prumycin were 144 and $155 \mathrm{mg} / \mathrm{kg}$, respectively. However, we did observe toxicity (loss of weight, mortality) when the compound was delivered by the s.c. route at $>30 \mathrm{mg} / \mathrm{kg} \times 4$. These effects are being investigated further.

The above results reveal that prumycin is a promising lead compound for a new type of antimalarial drug. Further investigation of the antimalarial potential of prumycin is in progress.

\section{Acknowledgments}

This work was supported, in part, by funds from the UNICEF/UNDP/World Bank/WHO Special Program for Research and Training in Tropical Diseases (grants ID A 10124), and Grants-in-Aid for Scientific Research (A) from the Ministry of Education, Culture, Sports, Science and Technology, Japan. A part of work was supported by The $21 \mathrm{st}$ Century COE program, the Ministry of Education, Culture, Sports, Science and Technology, Japan. We are grateful to Dr. 
K. HATA, JPMW Coordination Center, for valuable discussion. We also thank Mr. Y. Kato and Ms. M. SuzuKI, the Kitasato Institute, for the antimalarial assay, Dr. J. NAMATAME, Kitasato Institute for Life Sciences, Kitasato University, for technical assistance.

\section{KAZUHIKO OTOGURO* AKI ISHIYAMA MIYUKI KOBAYASHI Hitomi SEKIGUCHI TAKASHI IZUHARA ${ }^{\dagger}$ TOSHIAKI SUNAZUKA ${ }^{\dagger}$ HIROSHI TOMODA ${ }^{\dagger}$ HARUKI YAMADA ${ }^{\dagger}$ SATOSHI ŌMURA ${ }^{\dagger}$}

Research Center for Tropical Diseases, The Kitasato Institute, ${ }^{\dagger}$ Kitasato Institute for Life Sciences, Kitasato University, 5-9-1 Shirokane, Minato-ku, Tokyo 108-8642, Japan

(Received March 8, 2004)

\section{References}

1) Otoguro, K.; A. Kohana, C. Manabe, A. Ishiyama, H. Ui, K. Siomi, H. Yamada \& S. Ōmura: Potent antimalarial activities of polyether antibiotic, X-206. J. Antibiotics 54: 658 663, 2001

2) Otoguro, K.; A. Ishiyama, H. Ui, M. Kobayashi, C. Manabe, G. Yan, Y. Takahashi, H. Tanaka, H. YAMADA \& S. ŌMURA: In vitro and in vivo antimalarial activities of the monoglycoside polyether antibiotic, K41 against drug resistant strains of Plasmodia. J. Antibiotics 55: 832 834, 2002

3) Otoguro, K.; H. Ui, A. Ishiyama, N. Aral, M. Kobayashi, Y. Takahashi, R. Masuma, K. Siomi, H. YAMADA \& S. ÖMURA: In vitro antimalarial activities of the microbial metabolites. J. Antibiotics 56: 322 324, 2003

4) Otoguro, K.; H. Ui, A. Ishiyama, M. Kobayashi, H. Togashi, Y. Takahashi, R. Masuma, H. TanaKa, H. TOMODA, H. YAmada \& S. ŌMURA: In vitro and in vivo antimalarial activities of a non-glycoside 18-member macrolide antibiotic, borrelidin, against drug-resistant strains of Plasmodia. J. Antibiotics 56: 727 729, 2003

5) Hata, T.; S. Ōmura, M. Katagiri, K. Atsumi, J. Awaya, S. Higashikawa, K. Yasui, H. Terada \& S. Kuyama: A new antifungal antibiotic, prumycin. J. Antibiotics 24: 900 901, 1971

6) Ōmura, S.; M. Katagiri, J. Awaya, K. Atsumi, R. Ōima, T. Hata, S. Higashikawa, K. Yasui, H. Terada \& S. KUYAMA: Production and isolation of a new antifungal antibiotic, prumycin, and taxonomic studies of Streptomyces sp., strain No. F-1028. Agr. Biol. Chem. 37: 2805 2812, 1973

7) Ōmura, S.; M. Katagiri, K. Atsumi, T. Hata, A. A. JAkubowski, E. B. Springs \& M. Tishiler: Structure of prumycin. J. Chem. Soc., Perkin Trans. I. 1974: $1627 \sim 1631,1974$

8) Okubo, S.; N. Nakamura, K. Ito, H. Marumo, M. TANAKA \& S. ŌMURA: Antitumor activity of prumycin. J. Antibiotics 32: 347 354, 1979

9) Okubo, S.; N. Nakamura, M. Morimoto, K. Mineura, H. Marumo \& S. ŌMURA: Studies on antitumor activity of prumycin. II. Studies on distribution and excretion of prumycin. J. Antibiotics 33: 221 225, 1980

10) Okubo, S.; N. NaKamura, M. Morimoto, K. Mineura, H. MARUMO \& S. ŌMURA: Studies on antitumor activity of prumycin. III. Mode of action of prumycin on Hela S-3 cells. J. Antibiotics 33: 226 230, 1980

11) Okubo, S.; M. Morimoto, K. Mineura, H. Marumo \& S. ŌMURA: Studies on antitumor activity of prumycin. IV. Effect of prumycin on mouse immune system. J. Antibiotics 33: 231 235, 1980

12) Schwartz, J. L.; M. Katagiri, S. ŌMura \& M. Tishiler: The mechanism of prumycin action. J. Antibiotics 27: 379 385, 1974

\footnotetext{
* Corresponding author: otoguro@lisci.kitasato-u.ac.jp
} 